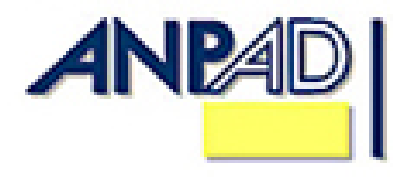

Available online at http://www.anpad.org.br/bar

BAR, Rio de Janeiro, v. 10, n. 4, art. 5, pp. 462-489, Oct./Dec. 2013

\title{
Multilatinas and Value Creation from Cross-Border Acquisitions: An Event Study Approach
}

Leon Chant Dakessian

E-mail address: lcdakessian@usp.br Universidade de São Paulo - FEA/USP Av. Prof. Luciano Gualberto, 908, 05508-010, São Paulo, SP, Brazil.

Paulo Roberto Feldmann E-mail address: feldmann@usp.br Universidade de São Paulo - FEA/USP Av. Prof. Luciano Gualberto, 908, 05508-010, São Paulo, SP, Brazil.

Received 29 April 2012; received in revised form 30 April 2013 (this paper has been with the authors for five revisions); accepted 7 May 2013; published online $1^{\text {st }}$ October 2013. 


\begin{abstract}
The central proposition of this paper is to assess the performance of cross-border acquisitions made by Multilatinas. Applying the event study method to a sample of 607 announcements of acquisitions during the period 1989-2011 by 182 Multilatinas from Argentina, Brazil, Chile, Colombia, Mexico, Peru and Venezuela, we conclude that: (a) on average, these announcements have a neutral impact on the short-term returns to acquiring companies' shareholders; (b) cross-sectional analysis reveals that relative size of the deals have a negative and significant effect on investors' reactions and; (c) unlike the institutional distance between home and host countries, cultural distance matters, since it has a negative and significant effect on the perceptions that investors have regarding the expected economic impact of acquirers' cross-border merger and acquisition (M\&A) decisions. Inasmuch as the market rationality assumption that underlies the event study method has been questioned, future research lines are proposed in order to search for alternative long-term performance constructs concerning M\&A processes in general that can: (a) shed light on the reality of value creation (and destruction) from cross-border acquisitions made by Multilatinas; and (b) contribute to strategy, international business and M\&A theories and practice.
\end{abstract}

Key words: internationalization; internalization theory; event study; multilatinas; abnormal returns. 


\section{Introduction}

The extensive and diversified academic production in internationalization and international business areas, particularly from the 1950s-1960s, has been a response to the increasing interest in transnational companies and their economic and social impacts not only on the economies from which they originate, but also on the countries hosting their foreign direct investments (FDIs).

Analogously to Coase's (1937) central proposition to understand and explain the reason for the existence of the firm, different theoretical streams - focused especially on corporations headquartered in developed countries - have striven to understand and explain the reason for a multinational enterprise (MNE) to exist, focusing on aspects linked to the extension and pattern of their activities.

While Hymer's (1976) seminal contribution and Caves' (1971) studies were based on the theoretical background of industrial organization and imperfect markets, it was only with Buckley and Casson $(1976,2003)$ that a more explicit treatment was given to the relationship between market imperfections and internationalization movements (Rugman, 1981).

Other theories endeavor to explain some specific phenomena, such as the expansion of NorthAmerican multinational companies in the post-war period (Vernon, 1979), as well as the internationalization patterns of Nordic multinational companies, commonly known as the Uppsala School, but also called the gradualism and learning model (Johanson \& Vahlne, 1977).

However, it was from the Ownership-Location-Internalization (OLI, or the eclectic) paradigm proposed by John Dunning $(1988,2001)$ - according to which the competitive advantages of multinational companies arise from the ownership of specific resources and capabilities (Ownership), from the geographical location of their operations (Location) and from the decision to internalize key activities (Internalization) rather than subcontracting them under market conditions - and the studies by Rugman $(1981,1996)$ and Hennart $(1977,1982)$ that internalization theory gained momentum to be considered the dominant paradigm to understand, explain and predict MNE internationalization strategies, both from developed countries and from emerging economies. Its interfaces with other theoretical streams, such as the Transaction Cost Theory (Hennart, 2010) and Strategic Management (Rugman \& Verbeke, 1992), have expanded its scope, comprehensiveness and predictive capability.

The emergence and accelerated expansion of multinational companies from emerging economies (EMNEs) are phenomena that have been increasingly prominent in the agenda of scholars, consulting firms and corporate communities worldwide, which gave rise to the question of whether existing international business (IB) theories adequately explain and predict their existence and behavior. As Ramamurti properly remarks,

the answer will depend upon what question one asks. Existing IB theories are quite adequate to explain why EMNEs internationalize, what challenges they face in host countries and why they prefer markets or hierarchies, but they fail to explain what the EMNEs' competitive advantages are, where these advantages come from, why some of them make substantial foreign direct investments in developed economies and compete head-on against Western MNEs (Ramamurti, 2009, p. 418).

As far as Latin America is concerned, the primary issue intriguing researchers is the fact that the region has produced a relatively small number of global and competitive companies. Factors commonly attributed to this fact include protectionist policies (through import substitution and tariff barriers), poorly developed capital markets, low investments in research and development (R\&D), low productivity, economic instability and the domination of internal markets by diversified family-owned conglomerates (or Business Groups) that, in many cases, have been protected against external competition (Casanova, 2009). 
Other causes are also mentioned, such as the presence of structural weaknesses related to poor educational systems, the low capacity for absorbing new technologies, the weak structure in Science and Technology, the delay in the development of telecommunications and the adoption of industrial policies that have poorly emphasized technology intensive industries (Feldmann, 2009).

The aforesaid factors may also have contributed to the late start of the internationalization processes of Latin American MNEs, or Multilatinas, as they are commonly known (Cuervo-Cazurra, 2010), even when compared to similar Asian companies. Analyzing internationalization strategies from a sample of 20 Multilatinas, Cuervo-Cazurra (2008) estimates an average period of 49 years between the foundation and the first foreign direct investment made by Brazilian multinational companies, and an average period of 53 years for Mexican multinationals.

This paper addresses a gap in IB research and literature. To our knowledge this is the first attempt to look at the performance of cross-border acquisition (CBA) activities developed by a sample of EMNEs located in Latin America, which can be regarded as a natural laboratory for the study of the internationalization process followed by companies, as a strategic response to the sweeping promarket reforms carried out by most of the countries in this region. The region also hosts a set of firms that pursued their international expansion strategies, driven mostly by the same market or natural resource-seeking motivations and using cross-border acquisition as a predominant entry mode (Chudnovsky, Kosacoff, \& López, 1999; Chudnovsky \& López, 2000; Fleury \& Fleury, 2011).

Our focus is on the Multilatinas, in particular assessment of their merger and acquisition (M\&A) activity performance, measured as investors' short-term reaction to announcements of their crossborder acquisitions, as well as factors that might explain the intensity and direction of these reactions.

The extant literature that deals with these issues usually focus on samples of acquirers located in developed economies. Those that focus their analysis on EMNEs, consider heterogeneous samples of acquisition announcements made by acquirers headquartered in regions (East Asia and Latin America, for example) that have shown significant differences regarding the evolutionary path of their national innovation and production systems (Cimoli, Dosi, \& Stiglitz, 2010).

The evolutionary paths of national systems of innovation are the outcome of, among other factors, choices made by governments regarding economic and industrial policies. They also shape the countries' location advantages (or L advantages) which, in turn, interact with and constrain domestic firms' specific advantages, or O advantages (Narula, 2011; Narula \& Dunning, 2000; Narula \& Nguyen, 2011) and the strategic spaces in which they can be positioned (Rugman, 2008).

These are the main arguments that justify our decision to restrict the sample to Latin American home countries which underwent similar economic reforms - with inward-looking state-led importsubstituting industrialization (ISI) policies dominating until 1980s, followed by the implementation of pro-market reforms starting in the 1980s and 1990s (Dau, 2012) - in contrast with East Asian countries that, since the 1960s, have adopted more flexible, new capability-building strategies, following a flying-geese pattern of production and upgrading (Palma, 2010).

The paper is structured as follows: in second section we present a theoretical background and the hypotheses to be tested; in third section we describe the method, data and econometric models; in fourth section we summarize the results and in final section we present our concluding remarks. 


\section{Theory and Hypotheses}

\section{International expansion of multilatinas}

As defined by Dunning and Lundan (2008a), a MNE (a group to which Multilatinas belong) is an enterprise that engages in foreign direct investment (FDI) and owns (or controls) value-added activities in more than one country.

Through these investments, they can grow either vertically - when the firm locates assets and/or employees in a foreign country with the purpose of securing the production of a raw material or an input component (backward integration) or the distribution and sale of a good or service (forward integration) - or horizontally, when they set up a plant or a service delivery facility in a foreign location with the goal of selling in that market, while keeping the production of the good or service in the home country (Guillén \& García-Canal, 2009).Vertical expansion is normally associated with natural resource or efficiency-seeking motivation, while horizontal expansion has to do with marketseeking motivation (see Dunning \& Lundan (2008a) for a detailed discussion on the four types of motivations that drive MNE internationalization strategies: natural resource-seeking, market-seeking, efficiency-seeking and strategic asset-seeking).

Recent literature on EMNE internationalization processes in general and of Multilatinas in particular has stressed that outward FDIs (OFDIs) - a mechanism through which cross-border acquisitions are implemented - cannot be explained without paying attention to the previous development of the domestic firms in their quest for generating ownership-based advantages that can be exploited abroad (Chudnovsky \& López, 2000; Cuervo-Cazurra \& Dau, 2008, 2009; Dau, 2012; Dominguez \& Brenes, 1997; Fleury \& Fleury, 2011).

Referred to collectively as the Washington Consensus, the structural reforms that have been implemented by Latin American governments (and other developing countries as well) in the late 1980s and early 1990s aimed at realigning institutional frameworks in order to reduce transaction costs, improve governance and facilitate market functions. Main components of these reforms included the achievement of fiscal discipline, reordered priorities concerning public expenditures, tax reforms, liberalized interest rates, competitive exchange rates, trade and inward FDI (IFDI) liberalization, market deregulation, privatization and securing property rights (Kuczynski \& Williamson, 2003; Lora, 2001; Rodrik, 2006; Williamson, 2004).

Despite contradictory views on the benefits of such reforms, recent empirical works have shown some evidence that domestic firms (state-owned and private) improved their profitability after their implementation (Cuervo-Cazurra \& Dau, 2009) and that their impact on the multinationality (measured by the number of foreign subsidiaries) has been higher on private firms than on state-owned companies (Dau, 2012). These authors have also identified the three mechanisms through which domestic firms improved their competitiveness: increasing operating efficiency, availability of better and cheaper inputs and an increase in competition intensity (Cuervo-Cazurra \& Dau, 2009).

Therefore, coming out stronger and more profitable after the restructuring process, a number of Multilatinas (and MNEs from other developing countries as well) put into effect aggressive international expansion plans, as one can observe the sheer number of M\&A transactions in which they have been involved as an acquiring party. As Chudnovsky and López (2000) found in their analysis, the bulk of the Multilatinas OFDIs have been characterized as market-seeking, with crossborder acquisition of existing firms as the preferred mode of entry.

Theoretical underpinnings of this international growth phenomenon can be found in internalization theory (Buckley \& Casson, 1976; Dunning, 2003; Henisz, 2003), in the OLI (or eclectic) paradigm (Dunning, 2001; Dunning \& Lundan, 2008a, 2008b) and in the dynamic version of the eclectic paradigm, the Investment Development Path framework (Dunning, 1986; Dunning \& Narula, 1996; Tolentino, 1987); each one being concerned with different research questions. 
Drawn upon the earlier insights of Coase (1937) and Penrose (1959), internalization theory is concerned with the intra-firm international division of labor and the costs and benefits (or relative efficiency) of alternative governance mechanisms. Its basic hypothesis is, first, that multinational hierarchies are, in comparison to inter-firm transactions regulated by market prices, an alternative solution for coordinating related value-added activities across national markets, and second, firms are likely to engage in FDI whenever they perceive that the net benefits of their common ownership of domestic and foreign activities will exceed those generated by external trading relationships (Dunning \& Lundan, 2008a). Implicit in this theoretical formulation is the concept of imperfect markets for knowledge and capability transfer across borders which cannot be efficiently carried out through markets. After honing their capabilities in response to pro-market reforms, internalization theory can explain why Multilatinas and other EMNEs leveraged and internalized their firm-specific advantages through cross-border acquisitions.

While accepting the logic of internalization theory, the OLI paradigm argues that there is a need to integrate location-specific variables with internalization-specific variables, to fully explain the amount and direction of MNE activities.

According to Dunning and Lundan (2008a) the level and structure of a firm's foreign valueadding activities will depend on four conditions being satisfied:

1. the possession of unique and sustainable O-specific advantages, such as access to intangible assets as well as to those that arise as a result of the common governance and coordination of related cross-border value-added activities, which lead to an increasing wealth creating capacity, reflected in asset value;

2. a firm's perception that internalization is the best option to add value to its O-assets, reflecting either greater organizational efficiency or a unique incentive structure of hierarchies;

3. assuming conditions 1 and 2 are satisfied, the extent to which the firm's strategic objectives are pursued through the exploitation of its O-advantages in a foreign location, which - assuming the heterogeneity regarding the spatial distribution of L-bound resources and capabilities - can confer competitive advantages to certain countries over those that do not possess them;

4. given an OLI configuration, the extent to which foreign production is consistent with a firm's stakeholders' long-term objectives and with the institutional foundations of its managerial and organizational strategy.

Predictions of the OLI paradigm can be stated as follows: the more a country's enterprises possess desirable O-based advantages the greater the incentive to internalize and the more they find it in their interest to access or exploit these advantages in a foreign market. Particular OLI variable configurations not only led to Multilatinas' international expansions, but also - due to differences in L-bound variables - explained the competitiveness of some countries in specific industries. This was the case for pharmaceuticals and steel in Argentina; textiles, steel, pulp and paper and air transportation in Brazil; electricity generation, pulp and paper, copper metallurgy and retail in Chile; and cement, glass, television and hotels in Mexico (Chudnovsky et al., 1999).

At a higher level of analysis, the investment development path (IDP) model is concerned with the dynamic interaction between firms' O-based advantages and countries' L-advantages in order to explain and predict patterns of inward foreign direct investment (IFDI) and outward foreign direct investment (OFDI) activities in a particular country. The hypothesis is that at lower levels of development (first stage), countries have very low capacity to attract FDIs, as neither domestic markets nor available resources offer business opportunities to MNEs; at this stage, domestic firms have no O-based advantages, which are necessary to compete abroad.

As countries develop (second stage), investment capital provides the basic physical and educational infrastructure leading to increases in the local resource productivity and capability upgrading; at this stage IFDIs (although in limited amounts) may play a relevant role in a country's 
industrialization process, especially if it is pursuing an export-led development strategy, as was the case for many Latin American countries in the late '60s and '70s.

In the third stage, income levels and industrial structures resemble those prevailing in some developed countries; government expenditures are mainly channeled to higher education and telecommunication infrastructure, whereas domestic firm competitiveness begins to rely less on access to natural resources and more on the managerial and organizational competences on which their Obased advantages will be built. These advantages are exploited initially through exports and then, as foreign sales and production costs increase, through market-seeking OFDIs (which explain the behavior and intensity of M\&A activity carried out by EMNEs in general and Multilatinas in particular). At this stage, in addition to resource or market-seeking investments, some firms may also begin to engage in efficiency and strategic resource-seeking activities, by way of acquisitions and strategic alliances with firms located in stage 4 and 5 economies.

Notwithstanding the fact that these three theoretical strands are able to explain and predict Multilatinas' choices in terms of FDI flows and internalization decisions, they are not explicit about investments' performance effects. However, considering that mergers and acquisitions activity is an important indicator of a firm's global competitiveness (Cantwell \& Barnard, 2008), and that crossborder acquisitions are one of the mechanisms through which firm-specific, O-based capabilities (particularly augmented and strengthened after pro-market reforms) are leveraged, one can speculate that acquiring firms' investors should demonstrate a positive reaction once acquisition decisions are disclosed. This leads us to formulate our first hypothesis:

H1: The announcements of cross-border acquisitions made by Multilatinas should, on average, generate positive impacts on short-term returns to their shareholders.

\section{Synergy realization in cross-border acquisitions}

The strenuous acquisition activity of EMNEs in general and of Multilatinas in particular over the last 20 years has heightened the debate about the performance of their cross-border M\&A deals.

Although it is well recognized that value is created after an acquisition and is the product of managerial action over time (Haspeslagh \& Jemison, 1991), in this paper we adopt the capital markets view of value creation, which asserts that the merits of an acquisition should be judged in terms of the immediate value created for the shareholders of the acquiring firms.

Compared to domestic M\&A, cross-border M\&As face a greater challenge since they involve the combination of two companies with different organizational cultures that are embedded in different national cultures. This forces the acquiring company to adapt not only to an unfamiliar national culture but also to a new organizational culture, a phenomenon Barkema, Bell and Pennings (1996) dubbed double-layered acculturation. The necessity for firms to grapple with national and organizational cultural issues can sometimes lead to cultural clashes or conflicts, which can trigger negative psychological effects in employees (acculturation stress). This can potentially derail the overall performance of the M\&A transaction, as it reduces employee commitment, productivity, retention and shareholder value (Larsson \& Lubatkin, 2001; Morosini, Shane, \& Singh, 1998).

Three main processes comprise a typical M\&A deal: due diligence, negotiation and integration, each of which characterized by its own dynamics and through which an acquiring company should improve its knowledge in order to reach a successful conclusion to the deal (Shimizu, Hitt, Vaidyanath, \& Pisano, 2004).

All of these processes are pretty much the same when cross-border acquisitions are compared with domestic transactions, but differences in institutional and cultural settings can introduce complications in specific parts of the deal. 
The integration process is the most critical for successful completion of a transaction, precisely because it is in this phase that synergies can be realized and the potential value of a transaction can be released, provided that institutional and cultural barriers that hinder knowledge and capability transfer, retention of key talents and a positive cooperation climate are eliminated or substantially reduced (Child, Faulkner, \& Pitkethly, 2001; Haspeslagh \& Jemison, 1991; Shimizu et al., 2004). This is because cultural values are deep-rooted and enduring, vary systematically between different societies and condition what is considered acceptable organizational practice.

On the institutional side, preferred management practices of acquiring companies will be shaped by the domestic institutional contexts in which they are embedded, implying that host country institutional environments may force acquiring firms to modify their preferred practices in order to comply with the regulatory provisions and other institutionally shaped features of each specific country (Child et al., 2001).

In the light of the above discussion we formulate the following hypotheses:

H2a: The institutional distance between home and host countries has a negative impact on the short-term return to acquiring companies' shareholders.

H2b: The cultural distance between home and host countries has a negative impact on the shortterm return to acquiring companies' shareholders.

\section{Method, Data, Sample Choice and Econometric Models}

Event study methodology has been widely used in empirical research, aimed at investigating the effects of economic phenomena on companies' market values. Despite the fact that this method was originally conceived to analyze events related to the corporate finance field, such as the effects of dividend and income announcements or the issuance of new shares, its general applicability has spread to several areas of social sciences. The utility of the method hinges on the assumption that, given market rationality, the effect of a certain event will be immediately reflected in the price of the asset under analysis, causing its economic impact to be observed throughout a relatively short period of time, which is centered on the date of its disclosure (MacKinlay, 1997). As this method is well known and widely applied in empirical research it will not be detailed here.

Test of hypothesis $\mathrm{H} 1$ as formulated in second section were carried out by testing the null hypothesis that the average cumulative abnormal return generated by the announcements is not significantly different from zero, under the normality and asymptotic convergence assumptions of the probability distribution of the test statistics (Campbell, Lo, \& MacKinlay, 1997).

Sample data was determined by a convenience criterion, covering publicly-held Multilatinas for which: detailed information about their international acquisitions was available in the Thomson Financial database; and the time series of stock and market index prices would be available in the Economatica database, which also provided the economic and financial data that were used in the cross-section analysis, notwithstanding the fact that this kind of data was not available for every acquirer firm.

The first sample employed to test hypothesis H1 was made up of 607 cross-border acquisition announcements during the sample period 1989-2011 by 182 publicly-held Multilatinas competing in 67 industries (see Table A1 in the Appendix): 16 from Argentina, 53 from Brazil, 37 from Chile, 13 from Colombia, 46 from Mexico, 13 from Peru and 4 from Venezuela.

Hypothesis $\mathrm{H} 2 \mathrm{a}$ and $\mathrm{H} 2 \mathrm{~b}$ were tested through an unbalanced panel data based on a much reduced sample using the Hausman-Taylor random-effect estimator, according to the following equation (Wooldridge, 2002): 


$$
\operatorname{car}_{i t}=\mathbf{z}_{\mathbf{i}} \gamma+\mathbf{x}_{\mathrm{it}} \beta+c_{i}+u_{i t}
$$

- $c_{i t}$ is the cumulative abnormal return generated by the announcement made by firm $i$ in time $t$ along event windows of varying lengths;

- $\quad \mathbf{z}_{\mathbf{i}}$ is a matrix that will contain time-invariant variables associated with dummies related to the home country, to the industry in which the acquirer competes and to their interactions as well;

. $\quad \mathbf{x}_{\mathbf{i t}}$ is a matrix that will contain the following time-varying variables:

Control variables: size of the acquiring firm (size), financial performance of the acquiring firm (perf), financial slack of the acquiring firm (slack), relative size of the deal (relsize), the over or under valuation of the currency of the home country against the US dollar at the day of the announcement (againstusd), percentage ownership sought by the acquirer in the target firm (control), and a dummy variable that equals 1 if the announcement date is in or after year 2000 and 0 otherwise (post_2000);

Explanatory variables: the institutional distance between the home and host countries (idistance), and the cultural distance between the home and host countries. See Table A2 in the Appendix for details on how these variables were calculated;

. $\quad c_{i}$ is the unobserved firm-specific heterogeneity, that is uncorrelated with elements of $\mathbf{z}_{\mathbf{i}}$;

$\gamma$ and $\beta$ are coefficient vectors to be estimated, and

$u_{i t}$ is the unobservable random error.

It is assumed that the three firm-specific variables in $\mathbf{x}_{\mathbf{i t}}$ (size, perf and slack) are endogenous and are correlated with $c_{i}$.

Table 1 depicts some characteristics of the data. Multilatinas in this sample are large companies measured by total assets. Average size of the acquiring firm is close to US $\$ 16.0$ billion, with significant variance between countries due to differences in the mix of industries in which they compete (excluding the big Brazilian banks, the average size shrinks to US\$5.7 billion). They are relatively profitable, generating an average return on equity (ROE) of 19\%, $45 \%$ of their total assets are financed by shareholder equity and they are, on average, five times bigger than their targets.

Table 2 shows, by home country, the timing of the 607 cross-border acquisition announcements from 1989 to 2011. Three-quarters of the announcements were made after 1999, a period in which Multilatinas aggressively accelerated their growth.

Table 3 presents the descriptive statistics and the pairwise correlation matrix with their associated significance level ${ }^{(1)}$. 
Table 1

\section{Sample Data}

\begin{tabular}{|c|c|c|c|c|c|c|c|c|}
\hline \multicolumn{9}{|c|}{ Acquirer's Home Country } \\
\hline Variables & Argentina & Brazil & Chile & Colombia & Mexico & Peru & Venezuela & All firms \\
\hline \multicolumn{9}{|l|}{ Size } \\
\hline $\begin{array}{l}\text { Mean (US\$ } \\
\text { billion) }\end{array}$ & 4.444 & 37.537 & 2.780 & 2.774 & 8.746 & 1.107 & 4.426 & 15.933 \\
\hline $\begin{array}{l}\text { SD (US\$ } \\
\text { billion) }\end{array}$ & 4.025 & 63.201 & 4.255 & 1.695 & 9.363 & 1.635 & 3.799 & 39.188 \\
\hline Skewness & 0.802 & 2.727 & 2.659 & 1.971 & 1.652 & 2.082 & 0.116 & 5.056 \\
\hline Kurtosis & 2.720 & 11.269 & 10.475 & 7.386 & 6.729 & 6.457 & 1.804 & 33.865 \\
\hline \multicolumn{9}{|l|}{ ROE } \\
\hline Mean & 0.139 & 0.289 & 0.139 & 0.101 & 0.170 & 0.120 & 0.070 & 0.192 \\
\hline SD & 0.086 & 1.232 & 0.157 & 0.069 & 0.123 & 0.135 & 0.045 & 0.696 \\
\hline Skewness & 1.064 & 12.912 & 4.113 & 0.918 & -0.435 & -1.182 & 1.588 & 22.498 \\
\hline Kurtosis & 3.293 & 173.219 & 26.158 & 4.068 & 6.966 & 4.827 & 3.839 & 536.112 \\
\hline \multicolumn{9}{|c|}{$\begin{array}{l}\text { Slack } \\
\text { (Equity/TA) }\end{array}$} \\
\hline Mean & 0,457 & 0.372 & 0.489 & 0.618 & 0.466 & 0.413 & 0.630 & 0.447 \\
\hline SD & 0,150 & 0.160 & 0.175 & 0.246 & 0.158 & 0.220 & 0.358 & 0.183 \\
\hline Skewness & $-0,494$ & -0.339 & -0.041 & -0.731 & 0.487 & -0.454 & -1.100 & 0.087 \\
\hline Kurtosis & 3,008 & 2.778 & 2.903 & 2.946 & 3.331 & 1.836 & 2.296 & 3.146 \\
\hline \multicolumn{9}{|c|}{$\begin{array}{l}\text { Relative Deal } \\
\text { Size }\end{array}$} \\
\hline Mean & 0.119 & 0.245 & 0.200 & 0.157 & 0.183 & 0.206 & 0.076 & 0.197 \\
\hline $\mathrm{SD}$ & 0.199 & 0.789 & 0.465 & 0.235 & 0.507 & 0.236 & 0.124 & 0.555 \\
\hline Skewness & 2.410 & 4.989 & 4.390 & 2.272 & 6.471 & 1.129 & 1.081 & 6.207 \\
\hline Kurtosis & 8.861 & 28.934 & 23.888 & 7.803 & 52.401 & 2.998 & 2.269 & 47.994 \\
\hline
\end{tabular}

Note. Source: elaborated by the authors. 
Table 2

\section{Timing of Announcements}

\begin{tabular}{|c|c|c|c|c|c|c|c|c|}
\hline \multirow{2}{*}{$\begin{array}{c}\text { Year of } \\
\text { Annoucement }\end{array}$} & \multicolumn{8}{|c|}{ Acquire's Home Country } \\
\hline & Argentina & Brazil & Chile & Colombia & Mexico & Peru & Venezuela & Total \\
\hline 1989 & 0 & 1 & 0 & 0 & 0 & 0 & 0 & 1 \\
\hline 1990 & 0 & 1 & 0 & 0 & 0 & 0 & 0 & 1 \\
\hline 1991 & 0 & 1 & 0 & 0 & 0 & 0 & 0 & 1 \\
\hline 1992 & 0 & 5 & 1 & 1 & 2 & 0 & 1 & 10 \\
\hline 1993 & 1 & 1 & 0 & 0 & 2 & 0 & 1 & 5 \\
\hline 1994 & 1 & 1 & 5 & 0 & 12 & 0 & 0 & 19 \\
\hline 1995 & 3 & 8 & 5 & 2 & 3 & 0 & 0 & 21 \\
\hline 1996 & 1 & 1 & 2 & 0 & 6 & 2 & 1 & 13 \\
\hline 1997 & 1 & 2 & 4 & 0 & 9 & 2 & 0 & 18 \\
\hline 1998 & 5 & 2 & 6 & 2 & 16 & 1 & 0 & 32 \\
\hline 1999 & 0 & 3 & 10 & 0 & 16 & 1 & 0 & 30 \\
\hline 2000 & 1 & 7 & 10 & 1 & 15 & 2 & 1 & 37 \\
\hline 2001 & 0 & 4 & 3 & 3 & 16 & 0 & 0 & 26 \\
\hline 2002 & 0 & 4 & 2 & 4 & 12 & 1 & 0 & 23 \\
\hline 2003 & 3 & 6 & 2 & 1 & 11 & 1 & 0 & 24 \\
\hline 2004 & 3 & 7 & 2 & 1 & 10 & 1 & 0 & 24 \\
\hline 2005 & 1 & 6 & 3 & 1 & 8 & 1 & 2 & 20 \\
\hline 2006 & 3 & 18 & 3 & 7 & 16 & 1 & 0 & 50 \\
\hline 2007 & 2 & 25 & 16 & 3 & 16 & 0 & 0 & 62 \\
\hline 2008 & 6 & 24 & 5 & 3 & 14 & 2 & 0 & 54 \\
\hline 2009 & 6 & 30 & 25 & 15 & 11 & 7 & 0 & 94 \\
\hline 2010 & 1 & 21 & 0 & 0 & 9 & 0 & 0 & 31 \\
\hline 2011 & 0 & 8 & 0 & 0 & 3 & 0 & 0 & 11 \\
\hline Total & 38 & 186 & 104 & 44 & 207 & 22 & 6 & 607 \\
\hline
\end{tabular}

Note. Source: elaborated by the authors. 
Table 3

Descriptive Statistics and Pairwise Correlation Matrix

\begin{tabular}{|c|c|c|c|c|c|c|c|c|c|c|c|c|c|}
\hline & Obs & Mean & Std. Dev. & [1] & [2] & [3] & [4] & [5] & [6] & [7] & {$[8]$} & [9] & {$[10]$} \\
\hline $1-\operatorname{car}[-5,0,+5]$ & 607 & 0.0010 & 0.0935 & 1.0000 & & & & & & & & & \\
\hline $2-\operatorname{size}^{a}$ & 552 & 3.5230 & 0.8169 & 0.0178 & 1.0000 & & & & & & & & \\
\hline 3 - perf & 600 & 0.1922 & 0.6961 & 0.0337 & -0.0672 & 1.0000 & & & & & & & \\
\hline 4 - slack & 552 & 0.4475 & 0.1826 & 0.0224 & $-0.3822 *$ & -0.0158 & 1.0000 & & & & & & \\
\hline 5 - relsize & 381 & 0.1966 & 0.5553 & -0.0695 & $-0.1861 *$ & 0.0744 & 0.0049 & 1.0000 & & & & & \\
\hline 6 - againstusd & 606 & 0.8350 & 0.3715 & -0.0712 & 0.0470 & 0.0303 & -0.0056 & 0.0547 & 1.0000 & & & & \\
\hline 7 - control & 427 & 0.7400 & 0.4391 & -0.0022 & -0.0413 & -0.0874 & $0.1028 *$ & 0.0746 & 0.0525 & 1.0000 & & & \\
\hline 8 - post_2000 & 607 & 0.7512 & 0.4327 & -0.0152 & $0.1952 *$ & -0.0457 & $-0.2244^{*}$ & 0.0496 & 0.0438 & $0.2247 *$ & 1.000 & & \\
\hline 9 - idistance & 606 & 1.1097 & 0.2839 & -0.0486 & $0.1792 *$ & 0.0287 & $-0.0858 *$ & 0.0885 & 0.0598 & 0.0577 & 0.0454 & 1.000 & \\
\hline 10 - cdistance & 576 & 1.2121 & 1.0821 & -0.0415 & 0.0164 & -0.0333 & 0.0657 & $0.1120^{*}$ & -0.0036 & -0.0098 & -0.0155 & $0.4964 *$ & 1.000 \\
\hline
\end{tabular}

Note. Source: elaborated by the authors.

${ }^{a}$ Measured in $\log _{10}$ of Total Assets

$* \mathrm{p}<.05$ 
Table 4

Cumulative Abnormal Returns to Acquirer Shareholders in Event Windows with Varying Lengths

\begin{tabular}{|c|c|c|c|c|c|c|c|}
\hline $\begin{array}{l}\text { Cumulative } \\
\text { Returns }\end{array}$ & $\begin{array}{c}\text { Length of } \\
\text { the Event } \\
\text { Window } \\
\text { (Days) }\end{array}$ & $\begin{array}{l}\text { Number of } \\
\text { Observations }\end{array}$ & $\begin{array}{c}\text { Average } \\
\text { Cumulative } \\
\text { Abnormal } \\
\text { Returns }\end{array}$ & $\begin{array}{c}\text { Standard } \\
\text { Error }\end{array}$ & p-value ${ }^{1}$ & $\begin{array}{c}\text { Wilcoxon } \\
\text { Signed } \\
\text { Rank Test }\end{array}$ & p-value ${ }^{2}$ \\
\hline Car [0] & 1 & 607 & 0.0011 & 0.0010 & 0.2777 & -0.3370 & 0.7363 \\
\hline $\operatorname{Car}[-1,0,+1]$ & 3 & 607 & 0.0004 & 0.0017 & 0.8372 & 0.1720 & 0.8633 \\
\hline $\operatorname{Car}[-2,0,+2]$ & 5 & 607 & 0.0010 & 0.0022 & 0.6679 & 0.3320 & 0.7402 \\
\hline $\operatorname{Car}[-3,0,+3]$ & 7 & 607 & 0.0005 & 0.0027 & 0.8560 & 0.3600 & 0.7191 \\
\hline $\operatorname{Car}[-4,0,+4]$ & 9 & 607 & 0.0006 & 0.0030 & 0.8461 & 0.3270 & 0.7437 \\
\hline $\operatorname{Car}[-5,0,+5]$ & 11 & 607 & 0.0010 & 0.0033 & 0.7691 & 0.0800 & 0.9366 \\
\hline
\end{tabular}

Note. Source: elaborated by the authors.

${ }^{1}$ Null Hypothesis: $C A R=0$; two-tailed tests; ${ }^{2}$ Null Hypothesis: proportion of positive $C A R$ is equal to 0,5 ; two-tailed tests. 
Table 5

OLS (Models I and II) and Hausman-Taylor (Models III to VI) Regressions; car[-5,0,+5] is the Dependent Variable

\begin{tabular}{|c|c|c|c|c|c|c|c|c|c|c|c|c|}
\hline & $\begin{array}{l}\text { Model I } \\
\text { (OLS) }\end{array}$ & $\mathrm{SE}^{1}$ & $\begin{array}{l}\text { Model II } \\
\text { (OLS) }\end{array}$ & $S^{1}$ & $\begin{array}{l}\text { Model III } \\
\text { Random } \\
\text { Effects }\end{array}$ & SE & $\begin{array}{l}\text { Model IV } \\
\text { Random } \\
\text { Effects }\end{array}$ & $\mathbf{S E}$ & $\begin{array}{l}\text { Model V } \\
\text { Random } \\
\text { Effects }\end{array}$ & $\mathbf{S E}$ & $\begin{array}{l}\text { Model VI } \\
\text { Random } \\
\text { Effects }\end{array}$ & $\mathbf{S E}$ \\
\hline \multicolumn{13}{|l|}{ Control Variables: } \\
\hline size & -0.0243 & 0.0203 & -0.0334 & 0.0200 & -0.0252 & 0.0185 & -0.0347 & 0.0231 & -0.0319 & 0.0209 & -0.0366 & 0.0222 \\
\hline perf & 0.1211 & 0.1028 & 0.1158 & 0.0982 & 0.1175 & 0.0628 & 0.1013 & 0.0655 & 0.0511 & 0.0685 & 0.0839 & 0.0690 \\
\hline slack & 0.0072 & 0.0774 & -0.0085 & 0.0795 & -0.0024 & 0.0703 & -0.0251 & 0.0714 & -0.0443 & 0.0817 & -0.0149 & 0.0742 \\
\hline relsize & $-0.0369 * * *$ & 0.0116 & $-0.0343^{*}$ & 0.0115 & $-0.0368 * * *$ & 0.0086 & $-0.0376^{* * *}$ & 0.0088 & $-0.0343^{* * *}$ & 0.0099 & $-0.0331 * * *$ & 0.0101 \\
\hline againstusd & 0.0079 & 0.0179 & 0.0058 & 0.0200 & 0.0030 & 0.0173 & 0.0095 & 0.0181 & 0.0043 & 0.0187 & 0.0052 & 0.0185 \\
\hline control & 0.0112 & 0.0134 & 0.0100 & 0.0144 & 0.0055 & 0.0118 & 0.0068 & 0.0123 & 0.0138 & 0.0131 & 0.0091 & 0.0137 \\
\hline post_2000 & -0.2539 & 0.1530 & 0.1080 & 0.0534 & 0.0138 & 0.0824 & 0.2778 & 0.2555 & 0.0648 & 0.0817 & 0.1397 & 0.0862 \\
\hline \multicolumn{13}{|c|}{ Explanatory Variables: } \\
\hline idistance & - & - & 0.0236 & 0.0412 & 0.0014 & 0.0265 & 0.0212 & 0.0311 & 0.0077 & 0.0320 & 0.0226 & 0.0347 \\
\hline cdistance & - & - & -0.0158 & 0.0093 & -0.0108 & 0.0064 & -0.0137 & 0.0071 & -0.0097 & 0.0072 & $-0.0160 *$ & 0.0074 \\
\hline constant & 0.3066 & 0.1657 & -0.0166 & 0.1345 & 0.0463 & 0.0989 & -0.1966 & 0.2349 & 0.0717 & 0.1360 & 0.0002 & 0.1368 \\
\hline Year effect & Yes & & Yes & & Yes & & Yes & & Yes & & Yes & \\
\hline Home country effect & Yes & & Yes & & No & & Yes & & Yes & & Yes & \\
\hline Industry effect & Yes & & Yes & & No & & No & & Yes & & Yes & \\
\hline $\begin{array}{l}\text { Interaction between } h \\
\text { country and industry } \\
\text { effects }\end{array}$ & Yes & & Yes & & No & & No & & No & & Yes & \\
\hline $\mathbf{N}$ & 275 & & 265 & & 265 & & 265 & & 265 & & 265 & \\
\hline $\mathbf{R}^{2}$ & 0.4517 & & 0.4772 & & - & & - & & - & & - & \\
\hline
\end{tabular}

Note. Source: elaborated by the authors.

${ }^{1}$ Cluster-adjusted, heteroskedasticity-robust standard errors

$* \mathrm{p}<0.05, * * \mathrm{p}<0.01, * * * \mathrm{p}<0.001$ 


\section{Results}

Table 4 summarizes the first part of the hypotheses testing. On announcement day, the sample average of abnormal return is just $0.11 \%$. Since standard error is $0.10 \%$, the null hypothesis that the announcement has no impact cannot be rejected. Non-parametric Wilcoxon signed test confirms this outcome. Increasing the length of the event window does not change this conclusion. Taking as an example the event window with 11 days, sample average $(0.10 \%)$ does not change much, but a larger standard error strongly supports the null hypothesis.

From the above, our hypothesis $\mathrm{H} 1$ that cross-border acquisition announcements made by Multilatinas have positive and significant impact on shareholder's returns is not supported by the data. In fact, announcements have, on average, a neutral effect on shareholder returns.

One possible explanation is that investors had the perception that investments made in crossborder acquisitions were at the same competitive parity with respect to incumbent players in those locations and, therefore, there was no reason to expect that these foreign operations would generate positive excess returns. Another possibility is that competitive bidding processes could have wiped out all excess economic value of the deals.

Findings from previous studies have shown mixed results. Aybar and Ficici's (2009) study of 433 cross-border acquisition announcements made by EMNEs originating in Latin America (accounting for 15\% of the total number of transactions) and Asia during the sample period 1991-2004 found that those announcements did not create value for acquiring companies' shareholders and pointed to value destruction in more than half of the transactions. Bhagat, Malhotra, and Zhu (2011), based on a sample of 698 cross-border acquisitions (CBAs) made by firms located in Brazil, China, India, Malaysia, Mexico, Philippines, Russia and South Africa, during the period January 1991 through December 2008, found that the emerging country acquirers experience a positive and a significant market response of $1.09 \%$ on announcement day. Gubbi, Aulakh, Ray, Sarkar and Chittoor (2010) constrained their sample to 425 CBAs by Indian companies during 2000-2007 period and found that the average cumulative abnormal return over a 11-day event windows was $2.58 \%$ and significant.

These discordant findings concerning short-term market reactions may be the outcome, among other methodological issues, of the substantial disparity concerning sample choices, where the mix between firms with market or natural resource-seeking motivations versus those with strategic assetseeking motivations differed substantially. It's been well researched that, for example, Asian and many Indian MNEs have made more inroads in technology and skill-intensive activities than their Latin American counterparts, in accordance with the technological accumulation path and outward orientation of the economic regimes that have been adopted by the governments of these newly industrialized economies (Chudnovsky \& López, 2000). This may be the reason why investors have demonstrated a positive reaction to cross-border acquisition announcements, when the target firms were located in advanced economic and institutional countries (Gubbi, Aulakh, Ray, Sarkar, \& Chittoor, 2010).

To conclude, the fact that empirical tests have generated contradictory findings concerning the testing of $\mathrm{H} 1$ would lead us to think that the cross-border M\&A practice is at odds with the previously discussed theoretical bodies used to explain and predict the internationalization movements and destination patterns of MNEs' (and Multilatinas' as well) foreign operations. The key issue here is that the incorporation and analysis of the factors that can contribute to explain and predict M\&A activities' performance implications are outside the boundaries of such theories and paradigms. In the next paragraphs we attempt to address some of these factors.

Results of the tests of hypotheses $\mathrm{H} 2 \mathrm{a}$ and $\mathrm{H} 2 \mathrm{~b}$ are summarized in Table 5. Models I and II consider traditional ordinary least square (OLS) estimators, without controlling for the unobservable firm-specific heterogeneity: the former restricts regressors to the control variables and the latter 
includes the explanatory variables. Dummies related to year, home country, industry in which acquirers compete and the interaction between home country and industry are included in both models. Relative size of the deal is the only statistically significant control variable, reflecting a negative (and pessimistic) reaction from investors as the transaction becomes bigger. None of the explanatory variables showed statistical significance.

Models III to VI are estimated through the random-effects Hausman-Taylor procedure that controls for the non-observed firm-specific heterogeneity, according to the specification outlined in section Results. This specification allows one to consistently estimate all coefficients when all timeinvariant variables are not correlated with the unobserved effect, but some of the time-varying regressors are (Hausman \& Taylor, 1981). Control dummies - year, home country, industry and interactions - are gradually inserted in the models (see the bottom part of Table 5). Another possibility is to consider a usual random-effect specification and proceed with a Hausman specification test in order to assess the reasonability of a random-effect structure against alternative fixed-effects. Notwithstanding the problem that the determination of the test statistics will drop all the time-invariant regressors (dummies) in the fixed-effect specification, the Hausman specification test (not reported) supports the random effect model $(p$-value $=0.9509)$.

Again, relative size of the deal is the only control variable that kept its relevance in all models. However, in Model VI, cultural distance showed a negative and significant effect (at 5\% significance level) which leads to the support of hypothesis $\mathrm{H} 2 \mathrm{~b}$ and to the rejection of hypothesis H2a, since institutional distance did not appear to be statistically significant.

Therefore, cultural distance matters. The more it increases, the more skeptical acquirers' investors become, presumably due to their perception of the effectiveness of the post-merger integration process. This is consistent with the findings of Datta and Puia (1995), analyzing a sample of 112 large cross-border acquisitions by US firms between 1978 and 1990.

Our contention is that for this sample, comprised by firms with a relatively homogeneous motivation to go abroad (market and natural resource-seeking), institutional distance is not a key issue regarding the post-acquisition integration process. In fact, as argued by Dunning and Lundan (2008a, p. 134),

reconciliation of country-specific institutional differences is likely to play a less significant role in the case of natural resource or capital intensive MNEs which involve relatively few and straightforward processes and transactions than in that of knowledge-intensive MNEs, which operate within complex networks of human interactions.

However, cultural issues will recur much more frequently as they are predominantly linked with human resource management activities and with organizational processes (Child et al., 2001).

Another explanation for the irrelevance of the institutional distance to explain shareholders' returns is the widely researched topic concerning the flexibility that Latin American firms have developed to circumvent institutional voids (Cuervo-Cazurra \& Genc, 2008, 2011; Khanna \& Palepu, 1997; Khanna, Palepu, \& Sinha, 2005).

We also conjecture that the negative investor reaction to sizable deals (with respect to the acquirer's size) may have to do with their perception of a hubris effect, a managerial phenomenon that has been a part of the M\&A research agenda for a long time (Hayward \& Hambrick, 1997; Hope, Thomas, \& Vyas, 2010; Mueller \& Yurtoglu, 2007; Roll, 1986). 


\section{Concluding Remarks}

Our endeavor in this paper is two-fold. First, to make a contribution to the EMNE research literature, looking at the relatively under-researched phenomenon of Multilatinas' internationalization strategy performance, bearing in mind that their predominant international growth motivations have been market and natural resource-seeking in orientation and that cross-border acquisition has been their preferred entry mode (Chudnovsky \& López, 2000; Fleury \& Fleury, 2011).

Second, we have investigated a rather contentious issue which is related to value creation and destruction from cross-border acquisitions made by EMNEs in general and we have concluded that announcements of cross-border acquisitions made by Multilatinas - despite their apparently competent strategic responses to pro-market reforms and their acquisitive prowess - did not, on average, create value for their shareholders. At best, these announcements had a neutral impact on short-term returns to these investors.

As previously discussed, the contradictory findings of past research that adopted similar scopes and the event study method are the outcome of differences in contexts, sampling choices, transaction characteristics and the staggering complexity of interactions between home and host countries within which organizational processes are embedded.

We have also emphasized that sampling choice really matters, because resource and capability building processes and the ensuing internationalization strategies (and FDI motivations) differ if one compares Latin American MNEs and their East Asian counterparts.

This paper also makes a contribution to strategic and international business practices, as far as the cross-section determinants of investors' reaction to CBA announcements have been identified and some hypotheses have been tested. Practitioners should consider that value can be created: (a) when superior knowledge and unique resources and capabilities are seamlessly transferred to and from foreign operations; and/or (b) when CBAs allow access to valuable, rare and inimitable resources and capabilities; and/or (c) when cultural issues are seriously addressed in M\&A processes; and (d) when capital markets are duly briefed on strategic and operational intent (up to the limit that confidentiality imposes), particularly when sizable targets are involved.

This paper has a limitation, inherent to the method that we employed to measure cross-border acquisitions performance, which is the ex-ante investor reaction to announcements made by acquirers. As mentioned elsewhere, the underlying assumption of the event study method is the market rationality that allows participants to correctly predict the economic impact of M\&A activity to be realized by acquiring companies over a very short time span and in a context of information asymmetry.

Recent research has challenged this assumption. Using a sample of 61 cross-border acquisitions made by British firms between 1988 and 1990, Schoenberg (2006) compared four alternative metrics to assess the performance of those acquisitions: cumulative abnormal returns (car), ex-post managers' assessments, divestment data and ex-post expert informants' assessments. His conclusion was that, with the exception of a positive relationship between managers' and expert informants' subjective assessments, no significant correlation was found between the performance data generated by the alternative metrics and also that ex-ante investors reaction to acquisitions announcements (measured by the car variable) exhibited little relation to corporate managers' ex-post assessments, which suggests the presence of information asymmetry between investors and the management of acquiring firms, particularly with respect to post-merger integration processes.

Employing an interesting research design, Zollo and Meier (2008) examine the issue of acquisition performance and, using factor analysis and structural equation modeling techniques applied to a sample of $211 \mathrm{M} \& \mathrm{~A}$ projects completed by a consulting firm's M\&A advisory practice between 1994 and 2001, the authors conclude that: M\&A performance is a multi-dimensional 
construct; there is a strong link between the integration process performance and overall long-term firm performance; and short-term window event studies are not linked to any other performance metrics.

Building on behavioral theory, psychology and economics, Schijven and Hitt (2012) developed a behavioral perspective of investor reactions to acquisition announcements. Applying these concepts on a multi-industry sample of acquisitions by North American firms, they concluded that boundedly rational investors infer management's perceptions about the economic potential of deals from the size of the premiums paid by acquiring firms and draw on additional publicly available information to assess the reliability of that perception.

We conclude this paper by asserting that our findings should be taken with caution. Future research on the performance assessment of cross border M\&A activities developed by Multilatinas must be conducted keeping in mind a scope that can make a complementary contribution to the one that is delivered by this paper, looking at creative ways to come up with theoretically more robust long-term performance indicators that allow researchers to assess long-term performance of these activities and help practitioners and their organizations to implement effective M\&A-related processes.

\title{
Note
}

\begin{abstract}
${ }^{1}$ We acknowledge the concern of one of the reviewers that Pearson correlation cannot be used to estimate the correlation coefficient involving a categorical and continuous (or scale) variables. In fact, the Pearson correlation estimation procedure requires that both variables be continuous, linearly related and normally distributed. As usual in quantitative-type research, the correlation matrix, even incorporating categorical and scale variables, gives a sense of the direction of the association between a pair of variables. It is not our intent to neither make any claim on the true correlation coefficient between any pair of variables nor make any statistical inference regarding the estimated correlations. We are aware that there are other appropriate statistical procedures to do so. Taking, for example, the relationship between the categorical variable control and the scale variable slack, what the correlation matrix is saying is that, in this sample, this relationship is positive and significant ( $\hat{\rho}=0.1028$, according to Table 3 ) and that it should be interpreted as follows: acquirers that sought a controlling interest in the target companies are associated with higher levels of slack. Another interpretation relates the size of acquirers and the timing of the announcement $(\hat{\rho}=0.1952)$ : announcements made in or after year 2000 are associated with acquirers that are bigger than those that made announcements before the year 2000. And so on.
\end{abstract}

\section{References}

Aybar, B., \& Ficici, A. (2009). Cross-border acquisitions and firm value: an analysis of emergingmarket multinationals. Journal of International Business Studies, 40(8), 1317-1338. doi: $10.1057 /$ jibs.2009.15

Barkema, H. G., Bell, J. H. J., \& Pennings, J. (1996). Foreign entry, cultural barriers and learning. Strategic Management Journal, 17(2), 151-166. doi: 10.1002/(SICI)10970266(199602)17:2<151::AID-SMJ799>3.0.CO;2-Z

Bhagat, S., Malhotra, S., \& Zhu, P. (2011). Emerging country cross-border acquisitions: characteristics, acquirer returns and cross-sectional determinants. Emerging Markets Review, 12(3), 250-271. doi: 10.1016/j.ememar.2011.04.001

Buckley, P. J., \& Casson, M. (1976). The future of the multinational enterprise. London: Macmillan.

Buckley, P. J., \& Casson, M. (2003). The future of the multinational enterprise in retrospect and in prospect. Journal of International Business Studies, 34(2), 219-222. doi: 10.1057/palgrave.jibs.8400024 
Campbell, J. Y., Lo, A. W., \& MacKinlay, A. C. (1997). The econometrics of financial markets. Princeton, NJ: Princeton University Press.

Cantwell, J., \& Barnard, H. (2008). Do firms from emerging markets have to invest abroad? Outward FDI and the competitiveness of firms. In K. P. Sauvant (Ed.), The rise of transnational corporations from emerging markets (pp. 55-85). Cheltenham, UK: Edward Elgar Publising Ltd.

Casanova, L. (2009). Global Latinas - Latin America's emerging multinationals. New York: Palgrave MacMillan.

Caves, R. E. (1971). International corporations: the industrial economics of foreign investment. Economica, 38(149), 1-27. doi: 10.2307/2551748

Child, J., Faulkner, D., \& Pitkethly, R. (2001). The management of international acquisitions. Oxford, UK: Oxford University Press.

Chudnovsky, D., Kosacoff, B., \& López, A. (1999). Las multinacionales latinoamericanas: sus estrategias en un mundo globalizado. Buenos Aires: Fondo de Cultura Economica.

Chudnovsky, D., \& López, A. (2000). A third wave of FDI from developing countries: Latin American TNCs in the 1990s. Transnational Corporations, 9(2), 31-74.

Cimoli, M., Dosi, G., \& Stiglitz, J. E. (2010). The political economy of capabilities accumulation: the past and future of policies for industrial development. In M. Cimoli, G. Dosi, \& J. E. Stiglitz (Eds.), Industrial policy and development - The political economy of capabilities accumulation (pp. 1-16). New York: Oxford University Press.

Coase, R. H. (1937). The nature of the firm. Economica, 4(16), 386-405. doi: 10.1111/j.14680335.1937.tb00002.x

Cuervo-Cazurra, A. (2008). The multinationalization of developing country MNEs: the case of multilatinas. Journal of International Management, 14(2), 138-154. doi: 10.1016/j.intman.2007.09.001

Cuervo-Cazurra, A. (2010). Multilatinas. Universia Business Review, 1(25), 14-33.

Cuervo-Cazurra, A., \& Dau, L. A. (2008, October). Structural reform and the accelerated multinationalization of developing-country firms. Proceedings of the Emerging Multinationals: Outward Foreign Direct Investment from Emerging and Developing Economies, Copenhagen, Dimanarca.

Cuervo-Cazurra, A., \& Dau, L. A. (2009). Promarket reforms and firm profitability in developing countries. Academy of Management Journal, 52(6), 1348-1368. doi: 10.5465/AMJ.2009.47085192

Cuervo-Cazurra, A., \& Genc, M. (2008). Transforming disadvantages into advantages: developingcountry MNEs in the least developed countries. Journal of International Business Studies, 39(6), 957-979. doi: 10.1057/palgrave.jibs. 8400390

Cuervo-Cazurra, A., \& Genc, M. E. (2011). Obligating, pressuring, and supporting dimensions of the environment and the non-market advantages of developing-country multinational companies. Journal of Management Studies, 48(2), 441-455. doi: 10.1111/j.1467-6486.2010.00964.x

Datta, D. K., \& Puia, G. (1995). Cross-border acquisitions: an examination of the influence of relatedness and cultural fit on shareholder value creation in US acquiring firms. MIR: Management International Review, 35(4), 337-359. 
Dau, L. A. (2012). Pro-market reforms and developing country multinational corporations. Global Strategy Journal, 2(3), 262-276. doi: 10.1111/j.2042-5805.2012.01033.x

Dominguez, L. V., \& Brenes, E. R. (1997). The internationalization of Latin American enterprises and market liberalization in the Americas: a vital linkage. Journal of Business Research, 38(1), 316. doi: 10.1016/S0148-2963(96)00113-0

Dunning, J. H. (1986). The investment development cycle revisited. Review of World Economics, 122(4), 667-676. doi: 10.1007/BF02707854

Dunning, J. H. (1988). The eclectic paradigm of international production: a restatement and some possible extensions. Journal of International Business Studies, 19(1), 1-31. doi: 10.1057/palgrave.jibs. 8490372

Dunning, J. H. (2001). The eclectic (OLI) paradigm of international production: past, present and future. International Journal of the Economics of Business, 8(2), 173-190. doi: $10.1080 / 13571510110051441$

Dunning, J. H. (2003). Some antecedents of internalization theory. Journal of International Business Studies, 34(2), 108-115. doi: 10.2307/3557146

Dunning, J. H., \& Lundan, S. M. (2008b). Institutions and the OLI paradigm of the multinational enterprise. Asia Pacific Journal of Management, 25(4), 573-593. doi: 10.1007/s10490-0079074-z

Dunning, J. H., \& Lundan, S. M. (2008a). Multinational enterprises and the global economy. Cheltenham, UK: Edward Elgar Publishing Limited.

Dunning, J. H., \& Narula, R. (1996). The investment development path revisited. In J. H. Dunning \& R. Narula (Eds.), Foreign direct investment and governments: Catalysts for economic restructuring (pp. 1-41). London: Routledge.

Feldmann, P. R. (2009). Empresas Latino-Americanas - oportunidades e ameaças no mundo globalizado. São Paulo: Editora Atlas.

Fleury, A. C. C., \& Fleury, M. T. L. (2011). Brazilian multinationals - competences for internationalization. New York: Cambridge University Press.

Gubbi, S. R., Aulakh, P. S., Ray, S., Sarkar, M. B., \& Chittoor, R. (2010). Do international acquisitions by emerging-economy firms create shareholder value? The case of Indian firms. Journal of International Business Studies, 41(3), 397-418. doi: 10.1057/jibs.2009.47

Guillén, M. F., \& García-Canal, E. (2009). The American model of the multinational firm and the "new" multinationals from emerging economies. Academy of Management Perspectives, 23(2), 23-35. doi: 10.5465/AMP.2009.39985538

Haspeslagh, P. C., \& Jemison, D. B. (1991). Managing acquisitions - creating value through corporate renewal. New York: The Free Press.

Hausman, J. A., \& Taylor, W. E. (1981). Panel data and unobservable individual effects. Econometrica: Journal of the Econometric Society, 49(6), 1377-1398.

Hayward, M. L. A., \& Hambrick, D. C. (1997). Explaining the premiums paid for large acquisitions: evidence of CEO hubris. Administrative Science Quarterly, 42(1) 103-127. doi: $10.2307 / 2393810$ 
Henisz, W. J. (2003). The power of the Buckley and Casson thesis: the ability to manage institutional idiosyncrasies. Journal of International Business Studies, 34(2), 173-184. doi: 10.1057/palgrave.jibs.8400015

Hennart, J.-F. (1977). A theory of foreign direct investment (Doctoral dissertation). University of Maryland, College Park, Maryland, US.

Hennart, J.-F. (1982). A theory of multinational enterprise. Ann Arbor: University of Michigan Press.

Hennart, J.-F. (2010). Transaction cost theory and international business. Journal of Retailing, 86(3), 257-269. doi: 10.1016/j.jretai.2010.07.009

Hofstede, G. (1997). Cultures and organizations: software of the mind. New York: McGraw Hill.

Hope, O. K., Thomas, W., \& Vyas, D. (2010). The cost of pride: why do firms from developing countries bid higher? Journal of International Business Studies, 42(1), 128-151. doi: $10.1057 /$ jibs.2010.5

Hymer, S. (1976). The international operations of national firms: a study of direct foreign investment. Cambridge, MA: The MIT Press.

Johanson, J., \& Vahlne, J.-E. (1977). The internationalization process of the firm-a model of knowledge development and increasing foreign market commitments. Journal of International Business Studies, 8(1), 23-32. doi: 10.1057/palgrave.jibs.8490676

Khanna, T., \& Palepu, K. (1997). Why focused strategies may be wrong for emerging markets. Harvard Business Review, 75(4), 41-51.

Khanna, T., Palepu, K. G., \& Sinha, J. (2005). Strategies that fit emerging markets. Harvard Business Review, 83(6), 63-74.

Kogut, B., \& Singh, H. (1988). The effect of national culture on the choice of entry mode. Journal of International Business Studies, 19(3), 411-432. doi: 10.1057/palgrave.jibs.8490394

Kuczynski, P.-P., \& Williamson, J. (2003). After the Washington consensus. Washington, DC: Institute for International Economics.

Larsson, R., \& Lubatkin, M. (2001). Achieving acculturation in mergers and acquisitions: an international case survey. Human Relations, 54(12), 1573-1607. doi: $10.1177 / 00187267015412002$

Lora, E. A. (2001). Structural reforms in Latin America: what has been reformed and how to measure it [Working Paper $\mathrm{N}^{\circ}$ 466]. Inter-American Development Bank, Washington, DC, US.

MacKinlay, A. C. (1997). Event studies in economics and finance. Journal of Economic Literature, 35(1), 13-39.

Morosini, P., Shane, S., \& Singh, H. (1998). National cultural distance and cross-border acquisition performance. Journal of International Business Studies, 29(1), 137-158. doi: 10.1057/palgrave.jibs. 8490029

Mueller, D. C., \& Yurtoglu, B. B. (2007). Corporate governance and the returns to acquiring firms' shareholders: an international comparison. Managerial and Decision Economics, 28(8), 879896. doi: $10.1002 /$ mde. 1365

Narula, R. (2011). Do we need different frameworks to explain infant MNES from developing countries? [Working Paper Series $\mathrm{N}^{\circ}$ 73]. Maastricht Economic and Social Research Institute on Innovation and Technology, Maastricht, The Netherlands. 
Narula, R., \& Dunning, J. H. (2000). Industrial development, globalization and multinational enterprises: new realities for developing countries. Oxford Development Studies, 28(2), 141167. doi: $10.1080 / 713688313$

Narula, R., \& Nguyen, Q. T. K. (2011). Emerging country MNEs and the role of home countries: separating fact from irrational expectations [Discussion Paper $\mathrm{N}^{\circ}$ 2011-001]. University of Reading, Reading, UK.

Palma, J. G. (2010). Flying geese and waddling ducks: the different capabilities of East Asia and Latin America to "demand-adapt" and "supply -upgrade" their export productive capacity. In M. Cimoli, G. Dosi, \& J. E. Stiglitz (Eds.), Industrial policy and development - The political economy of capabilities accumulation (pp. 1-16). New York: Oxford University Press.

Penrose, E. T. (1959). The theory of the growth of the firm. Oxford: Basil Blackwell.

Ramamurti, R. (2009). What have we learned about emerging market MNEs? In R. Ramamurti \& J. V. Singh (Eds.), Emerging multinationals in emerging markets (pp. 399-425). New York: Cambridge University Press.

Rodrik, D. (2006). Goodbye Washington consensus, hello Washington confusion? A review of the world bank's economic growth in the 1990s: learning from a decade of reform. Journal of Economic Literature, 44(4), 973-987. doi: 10.1257/jel.44.4.973

Roll, R. (1986). The hubris hypothesis of corporate takeovers. The Journal of Business, 59(2), 197216. doi: $10.2307 / 2353017$

Rugman, A. M. (1981). Inside the multinationals: the economics of internal markets. London: Croom Helm.

Rugman, A. M. (1996). The theory of multinational enterprises. Cheltenham, UK: Edward Elgar.

Rugman, A. M. (2008). How global are TNCs from emerging markets. In K. P. Sauvant (Ed.), The rise of transnational corporations FRO emerging markets (pp. 86-106). Cheltenham, UK: Edward Elgar Publising Ltd.

Rugman, A. M., \& Verbeke, A. (1992). A note on the transnational solution and the transaction cost theory of multinational strategic management. Journal of International Business Studies, 23(4), 761-771. doi: 10.1057/palgrave.jibs.8490287

Schijven, M., \& Hitt, M. A. (2012). The vicarious wisdom of crowds: toward a behavioral perspective on investor reactions to acquisition announcements. Strategic Management Journal, 33(11), 1247-1268. doi: 10.1002/smj.1984

Schoenberg, R. (2006). Measuring the performance of corporate acquisitions: an empirical comparison of alternative metrics. British Journal of Management, 17(4), 361-370. doi: 10.1111/j.14678551.2006.00488.x

Shimizu, K., Hitt, M. A., Vaidyanath, D., \& Pisano, V. (2004). Theoretical foundations of crossborder mergers and acquisitions: a review of current research and recommendations for the future. Journal of International Management, 10(3), 307-353. doi: 10.1016/j.intman.2004.05.005

The Heritage Foundation. (1995). 2011 index of economic freedom (Explore the data. All index data). Retrieved from http://www.heritage.org/index/explore?view=by-region-country-year\#top

The Heritage Foundation. (1996). 2011 index of economic freedom (Explore the data. All index data). Retrieved from http://www.heritage.org/index/explore?view=by-region-country-year\#top 
The Heritage Foundation. (1997). 2011 index of economic freedom (Explore the data. All index data). Retrieved from http://www.heritage.org/index/explore?view=by-region-country-year\#top

The Heritage Foundation. (1998). 2011 index of economic freedom (Explore the data. All index data). Retrieved from http://www.heritage.org/index/explore?view=by-region-country-year\#top

The Heritage Foundation. (1999). 2011 index of economic freedom (Explore the data. All index data). Retrieved from http://www.heritage.org/index/explore?view=by-region-country-year\#top

The Heritage Foundation. (2000). 2011 index of economic freedom (Explore the data. All index data). Retrieved from http://www.heritage.org/index/explore?view=by-region-country-year\#top

The Heritage Foundation. (2001). 2011 index of economic freedom (Explore the data. All index data). Retrieved from http://www.heritage.org/index/explore?view=by-region-country-year\#top

The Heritage Foundation. (2002). 2011 index of economic freedom (Explore the data. All index data). Retrieved from http://www.heritage.org/index/explore?view=by-region-country-year\#top

The Heritage Foundation. (2003). 2011 index of economic freedom (Explore the data. All index data). Retrieved from http://www.heritage.org/index/explore?view=by-region-country-year\#top

The Heritage Foundation. (2004). 2011 index of economic freedom (Explore the data. All index data). Retrieved from http://www.heritage.org/index/explore?view=by-region-country-year\#top

The Heritage Foundation. (2005). 2011 index of economic freedom (Explore the data. All index data). Retrieved from http://www.heritage.org/index/explore?view=by-region-country-year\#top

The Heritage Foundation. (2006). 2011 index of economic freedom (Explore the data. All index data). Retrieved from http://www.heritage.org/index/explore?view=by-region-country-year\#top

The Heritage Foundation. (2007). 2011 index of economic freedom (Explore the data. All index data). Retrieved from http://www.heritage.org/index/explore?view=by-region-country-year\#top

The Heritage Foundation. (2008). 2011 index of economic freedom (Explore the data. All index data). Retrieved from http://www.heritage.org/index/explore?view=by-region-country-year\#top

The Heritage Foundation. (2009). 2011 index of economic freedom (Explore the data. All index data). Retrieved from http://www.heritage.org/index/explore?view=by-region-country-year\#top

The Heritage Foundation. (2010). 2011 index of economic freedom (Explore the data. All index data). Retrieved from http://www.heritage.org/index/explore?view=by-region-country-year\#top

The Heritage Foundation. (2011). 2011 index of economic freedom (Explore the data. All index data). Retrieved from http://www.heritage.org/index/explore?view=by-region-country-year\#top

Tolentino, P. E. (1987). The global shift in international production: the growth of multinational enterprises from the developing countries; the Philippines (Doctoral thesis). University of Reading, Reading, UK.

Vernon, R. (1979). The product cycle hypothesis in a new international environment. Oxford Bulletin of Economics \& Statistics, 41(4), 255-267. doi: 10.1111/j.1468-0084.1979.mp41004002.x

Williamson, J. (2004). The strange history of the Washington consensus. Journal of Post Keynesian Economics, 27(2), 195-206.

Wooldridge, J. M. (2002). Econometric analysis of cross section and panel data. Cambridge, Mass.: The MIT Press. 
Zollo, M., \& Meier, D. (2008). What is M\&A performance? Academy of Management Perspectives, 22(3), 55-77. doi: 10.5465/AMP.2008.34587995 


\section{APPENDIX}

Table A1

Acquiring Firm Industries per Country, in Decreasing Order of the Number of Observations

\begin{tabular}{|c|c|c|c|c|c|c|c|c|c|}
\hline $\begin{array}{l}\text { NAICS } \\
\text { Code }\end{array}$ & Industry & ARG & BRA & CHL & COL & MEX & PER & VEN & Total \\
\hline 517 & Telecommunications & & 1 & 3 & & 53 & & & 57 \\
\hline 3121 & Beverage Manufacturing & 1 & 13 & 13 & 10 & 10 & 1 & 1 & 49 \\
\hline 3273 & $\begin{array}{l}\text { Cement and Concrete Product } \\
\text { Manufacturing }\end{array}$ & & & 2 & 3 & 41 & 1 & & 47 \\
\hline 5221 & Depository Credit Intermediation & 4 & 17 & & 7 & 10 & 4 & & 42 \\
\hline 3312 & $\begin{array}{l}\text { Steel Product Manufacturing } \\
\text { from Purchased Steel }\end{array}$ & 13 & 21 & 5 & & 1 & & & 40 \\
\hline 211 & Oil and Gas Extraction & 8 & 31 & & & & & & 39 \\
\hline 999 & Not Specified & 7 & 3 & & & 23 & & 1 & 34 \\
\hline 2122 & Metal Ore Mining & & 24 & 4 & & & 4 & & 32 \\
\hline 2211 & $\begin{array}{l}\text { Electric Power Generation, } \\
\text { Transmission and Distribution }\end{array}$ & & 5 & 14 & 7 & & & 2 & 28 \\
\hline 3118 & $\begin{array}{l}\text { Bakeries and Tortilla } \\
\text { Manufacturing }\end{array}$ & & & & & 15 & & & 15 \\
\hline 3116 & $\begin{array}{l}\text { Animal Slaughtering and } \\
\text { Processing }\end{array}$ & & 14 & & & & & & 14 \\
\hline 5151 & $\begin{array}{l}\text { Radio and Television } \\
\text { Broadcasting }\end{array}$ & & & & & 14 & & & 14 \\
\hline 3259 & $\begin{array}{l}\text { Other Chemical Product and } \\
\text { Preparation Manufacturing }\end{array}$ & & & & & 12 & & & 12 \\
\hline 4529 & $\begin{array}{l}\text { Other General Merchandise } \\
\text { Stores }\end{array}$ & & & 8 & & 3 & & & 11 \\
\hline 4811 & Scheduled Air Transportation & & 1 & 10 & & & & & 11 \\
\hline 551 & $\begin{array}{l}\text { Management of Companies and } \\
\text { Enterprises }\end{array}$ & & 6 & & & & 3 & & 9 \\
\hline 2212 & Natural Gas Distribution & 1 & & 2 & 6 & & & & 9 \\
\hline 5259 & $\begin{array}{l}\text { Other Investment Pools and } \\
\text { Funds }\end{array}$ & & & 9 & & & & & 9 \\
\hline 3113 & $\begin{array}{l}\text { Sugar and Confectionery Product } \\
\text { Manufacturing }\end{array}$ & & 1 & 1 & 6 & & & & 8 \\
\hline 3119 & Other Food Manufacturing & & & & & 5 & 2 & & 7 \\
\hline 5415 & $\begin{array}{l}\text { Computer Systems Design and } \\
\text { Related Services }\end{array}$ & 2 & & 4 & & & & & 6 \\
\hline 3321 & Forging and Stamping & & 5 & & & 1 & & & 6 \\
\hline 3112 & Grain and Oilseed Milling & & & & & 6 & & & 6 \\
\hline 3221 & $\begin{array}{l}\text { Pulp, Paper, and Paperboard } \\
\text { Mills }\end{array}$ & & & 5 & & 1 & & & 6 \\
\hline 3336 & $\begin{array}{l}\text { Engine, Turbine, and Power } \\
\text { Transmission Equipment } \\
\text { Manufacturing }\end{array}$ & & 5 & & & & & & 5 \\
\hline
\end{tabular}


Table A1 (continued)

\begin{tabular}{|c|c|c|c|c|c|c|c|c|c|}
\hline $\begin{array}{l}\text { NAICS } \\
\text { Code }\end{array}$ & Industry & ARG & BRA & CHL & COL & MEX & PER & VEN & Total \\
\hline 3363 & $\begin{array}{l}\text { Motor Vehicle Parts } \\
\text { Manufacturing }\end{array}$ & & 5 & & & & & & 5 \\
\hline 2361 & $\begin{array}{l}\text { Residential Building } \\
\text { Construction }\end{array}$ & & 2 & 1 & & & 2 & & 5 \\
\hline 3251 & Basic Chemical Manufacturing & & 4 & & & & & & 4 \\
\hline 3115 & Dairy Product Manufacturing & & 1 & & & & 3 & & 4 \\
\hline 4831 & $\begin{array}{l}\text { Deep Sea, Coastal, and Great } \\
\text { Lakes Water Transportation }\end{array}$ & & & 4 & & & & & 4 \\
\hline 3162 & Footwear Manufacturing & & 4 & & & & & & 4 \\
\hline 3272 & $\begin{array}{l}\text { Glass and Glass Product } \\
\text { Manufacturing }\end{array}$ & & & 1 & & 3 & & & 4 \\
\hline 3399 & $\begin{array}{l}\text { Other Miscellaneous } \\
\text { Manufacturing }\end{array}$ & & 2 & 2 & & & & & 4 \\
\hline 5223 & $\begin{array}{l}\text { Activities Related to Credit } \\
\text { Intermediation }\end{array}$ & & & & 2 & 1 & & & 3 \\
\hline 446 & Health and Personal Care Stores & & & 3 & & & & & 3 \\
\hline 3362 & $\begin{array}{l}\text { Motor Vehicle Body and Trailer } \\
\text { Manufacturing }\end{array}$ & & 3 & & & & & & 3 \\
\hline 6211 & Offices of Physicians & & & 3 & & & & & 3 \\
\hline 1111 & Oilseed and Grain Farming & & & & & 3 & & & 3 \\
\hline 3334 & $\begin{array}{l}\text { Ventilation, Heating, Air- } \\
\text { Conditioning, and Commercial } \\
\text { Refrigeration Equipment } \\
\text { Manufacturing }\end{array}$ & & 3 & & & & & & 3 \\
\hline 3341 & $\begin{array}{l}\text { Computer and Peripheral } \\
\text { Equipment Manufacturing }\end{array}$ & & 1 & & & 1 & & & 2 \\
\hline 3322 & $\begin{array}{l}\text { Cutlery and Handtool } \\
\text { Manufacturing }\end{array}$ & & & & & 2 & & & 2 \\
\hline 3332 & $\begin{array}{l}\text { Industrial Machinery } \\
\text { Manufacturing }\end{array}$ & & 2 & & & & & & 2 \\
\hline 5251 & $\begin{array}{l}\text { Insurance and Employee Benefit } \\
\text { Funds }\end{array}$ & & & 2 & & & & & 2 \\
\hline 3311 & $\begin{array}{l}\text { Iron and Steel Mills and } \\
\text { Ferroalloy Manufacturing }\end{array}$ & & & 2 & & & & & 2 \\
\hline 4238 & $\begin{array}{l}\text { Machinery, Equipment, and } \\
\text { Supplies Merchant Wholesalers }\end{array}$ & & & & & & 2 & & 2 \\
\hline 2123 & $\begin{array}{l}\text { Nonmetallic Mineral Mining and } \\
\text { Quarrying }\end{array}$ & & & 2 & & & & & 2 \\
\hline 5239 & $\begin{array}{l}\text { Other Financial Investment } \\
\text { Activities }\end{array}$ & & & 1 & 1 & & & & 2 \\
\hline 3255 & $\begin{array}{l}\text { Paint, Coating, and Adhesive } \\
\text { Manufacturing }\end{array}$ & & & & & & & 2 & 2 \\
\hline 5232 & $\begin{array}{l}\text { Securities and Commodity } \\
\text { Exchanges }\end{array}$ & & 1 & & 1 & & & & 2 \\
\hline 2213 & $\begin{array}{l}\text { Water, Sewage and Other } \\
\text { Systems }\end{array}$ & & 2 & & & & & & 2 \\
\hline
\end{tabular}


Table A1 (continued)

\begin{tabular}{|c|c|c|c|c|c|c|c|c|c|}
\hline $\begin{array}{l}\text { NAICS } \\
\text { Code }\end{array}$ & Industry & ARG & BRA & CHL & COL & MEX & PER & VEN & Total \\
\hline 3364 & $\begin{array}{l}\text { Aerospace Product and Parts } \\
\text { Manufacturing }\end{array}$ & & 1 & & & & & & 1 \\
\hline 3331 & $\begin{array}{l}\text { Agriculture, Construction, and } \\
\text { Mining Machinery } \\
\text { Manufacturing }\end{array}$ & 1 & & & & & & & 1 \\
\hline 3323 & $\begin{array}{l}\text { Architectural and Structural } \\
\text { Metals Manufacturing }\end{array}$ & & & & & 1 & & & 1 \\
\hline 5321 & $\begin{array}{l}\text { Automotive Equipment Rental } \\
\text { and Leasing }\end{array}$ & & 1 & & & & & & 1 \\
\hline 3222 & $\begin{array}{l}\text { Converted Paper Product } \\
\text { Manufacturing }\end{array}$ & & & 1 & & & & & 1 \\
\hline 3152 & $\begin{array}{l}\text { Cut and Sew Apparel } \\
\text { Manufacturing }\end{array}$ & & 1 & & & & & & 1 \\
\hline 4521 & Department Stores & & 1 & & & & & & 1 \\
\hline 3132 & Fabric Mills & & 1 & & & & & & 1 \\
\hline 1132 & $\begin{array}{l}\text { Forest Nurseries and Gathering } \\
\text { of Forest Products }\end{array}$ & & & 1 & & & & & 1 \\
\hline 1113 & Fruit and Tree Nut Farming & 1 & & & & & & & 1 \\
\hline 447 & Gasoline Stations & & & 1 & & & & & 1 \\
\hline 3329 & $\begin{array}{l}\text { Other Fabricated Metal Product } \\
\text { Manufacturing }\end{array}$ & & 1 & & & & & & 1 \\
\hline 3339 & $\begin{array}{l}\text { Other General Purpose } \\
\text { Machinery Manufacturing }\end{array}$ & & & & & 1 & & & 1 \\
\hline 3219 & $\begin{array}{l}\text { Other Wood Product } \\
\text { Manufacturing }\end{array}$ & & 1 & & & & & & 1 \\
\hline 3261 & Plastics Product Manufacturing & & 1 & & & & & & 1 \\
\hline 5231 & $\begin{array}{l}\text { Securities and Commodity } \\
\text { Contracts Intermediation and } \\
\text { Brokerage }\end{array}$ & & & & 1 & & & & 1 \\
\hline 3256 & $\begin{array}{l}\text { Soap, Cleaning Compound, and } \\
\text { Toilet Preparation Manufacturing }\end{array}$ & & 1 & & & & & & 1 \\
\hline & Total & 38 & 186 & 104 & 44 & 207 & 22 & 6 & 607 \\
\hline
\end{tabular}


Table A2

\section{Variable Description}

\begin{tabular}{|c|c|}
\hline Control Variables & Description \\
\hline size & $\begin{array}{l}\text { Size of the acquiring firm, measured as the average of the } \log _{10} \text { (Total Assets), } \\
\text { considering the three fiscal years before the announcement year. }\end{array}$ \\
\hline perf & $\begin{array}{l}\text { Performance of the acquiring firm, measured as the average return on equity (ROE), } \\
\text { considering the three fiscal years before the announcement year. }\end{array}$ \\
\hline slack & $\begin{array}{l}\text { Financial slack of the acquiring firm, measured as the average of book value of } \\
\text { Equity divided by Total Assets (Equity/TA), considering the three fiscal years before } \\
\text { the announcement year. }\end{array}$ \\
\hline relsize & $\begin{array}{l}\text { Relative size of the deal, measured as the value of the target company divided by the } \\
\text { book value of shareholders Equity of the acquiring company at end of the fiscal year } \\
\text { preceding the announcement year. }\end{array}$ \\
\hline againstusd & $\begin{array}{l}\text { Binary variable that equals one if the real exchange rate of the home country's } \\
\text { currency at the announcement date is overvalued against the US dollar (i.e. below), } \\
\text { with respect to the previous 5-year daily average and equals to zero otherwise. }\end{array}$ \\
\hline control & $\begin{array}{l}\text { Binary variable that equals to one if the percentage control sought by the acquirer in } \\
\text { the target company is greater than } 50 \% \text { and equals zero otherwise. }\end{array}$ \\
\hline post_2000 & $\begin{array}{l}\text { Binary variable that equals to one if the announcement is made in or after year } 2000 \\
\text { and zero otherwise. }\end{array}$ \\
\hline \multicolumn{2}{|c|}{ Explanatory Variables } \\
\hline idistance & $\begin{array}{l}\text { Institutional distance between host and home countries, based on the four institutional } \\
\text { dimensions calculated by The Heritage Foundation }(1995,1996,1997,1998,1999 \text {, } \\
\text { 2000, 2001, 2002, 2003, 2004, 2005, 2006, 2007, 2008, 2009, 2010, 2011): Business } \\
\text { Freedom, Trade Freedom, Investment Freedom and Property Rights. The } \\
\text { combination procedure of these four dimension follows Gubbi et al. (2010). }\end{array}$ \\
\hline cdistance & $\begin{array}{l}\text { Cultural distance between host and home countries, based on combining Hofstede's } \\
\text { four (Hofstede, 1997) cultural dimensions: Power Distance, Individualism, } \\
\text { Masculinity/Femininity and Uncertainty Avoidance, a methodology proposed by } \\
\text { Kogut and Singh (1988). }\end{array}$ \\
\hline
\end{tabular}

